\title{
Article
}

\section{Police Bullshit}

Taking Brutal Police Talk Less Seriously

\author{
David Sausdal \\ University of Copenhagen
}

\begin{abstract}
The police say brutal things. Research has documented how officers, when amongst themselves, talk about people in derogatory ways or openly fantasize about the use of excessive violence. In the literature, such backstage talk is in general analyzed in two ways: It is understood as proof of how the police really think - as evidencing police (im)morality or misconduct. Alternatively, scholars argue that police officers' transgressive talk is a warped yet nevertheless meaningful and meaning-generating way for them to deal with their, at times, harsh profession. Certainly, both these means of analysis resonate with the empirical material of this article - an empirical material stemming from an ethnographic study of two Danish detective units. Yet, as this article argues, simply applying this analytical twofold would risk misrepresenting or, perhaps rather, overinterpreting the indeed brutal things the Danish detectives said. While some of the detectives' language could/ should be understood as representing police immorality or reflecting their troublesome profession, this article proposes a counterintuitive reading, namely that their vicious words were, paradoxically, often analytically ordinary. They were examples of "bullshitting" (Frankfurt 2009) - a genre of offensive talk yet, nevertheless, a genre with no specific internal nor intended meaning to it. Therefore, although (police and others') bullshit is extremely evocative, and thus includes the risk of drawing the ethnographer in, one should be cautious about taking it too seriously. At least when it came to these Danish detectives, their vicious words habitually had little purchase on their general perceptions or practices. Their words were certainly distasteful but, really, just bullshit.
\end{abstract}

\section{Keywords}

Police, (im)morality, canteen culture, masculinity, storytelling, banter, jargon, bullshit, ethnography 
'One of the most salient features of our culture is that there is so much bullshit. Everyone knows this'

- Harry Frankfurt, On Bullshit

\section{Introduction}

"Tick, tick, boom!" a Danish police detective shouts enthusiastically on this otherwise slow Copenhagen afternoon. He is sitting at his desk, his face pressed against the screen in front of him. "Come over here," he urges his colleagues. "The ticker is going up and up. There! One more!" he bellows, as other detectives gather around him. During the months spent with this particular Danish detective unit, observing their investigations of transnational crimes (mostly organized property crimes), I have rarely encountered such jubilation. Intrigued, I squeeze through the crowd of detectives who are cheering on what I understand to be an increasing tally of some sort. Finally able to see the screen, I realize that the detectives are looking at a tabloid newspaper's website reporting a growing number of civilian casualties in a foreign country. Stupefied, and fairly shocked, I return to my corner of the office. From there, I watch more police officers come and go, until they, relatively quickly, lose interest and return to their respective duties.

Unfortunately, I cannot disclose any specific details about what it was the website was reporting; this would bring me into conflict with the contractual and ethical commitments of my ethnographic study of the two Danish detective units from which this article's empirical material originates. This is a study I began in 2015 and keep returning to, focused on how the Danish police force, as a primary state provider of crime prevention, control, security and public safety, deals with an increasing number of criminal issues stemming from outside Denmark (Sausdal 2018b, a, 2019b, a). Furthermore, as this article elaborates, disclosing the finer details of the detectives' shocking behavior would falsely eschew their wider representation as professionals and as human beings. In their actual meetings and dealings with members of the public they, for example, didn't exhibit any clear-cut signs of prejudice, nor did they apply any unmistakable amount of excessive force. The same can be said in relation to how they most of the time carried themselves "backstage" (Goffman 1978), i.e. when only amongst themselves (and me) in their offices, meeting rooms, cars, canteen, etc. Here, besides flashes of worded viciousness and vulgarity as in the above example, they were neither openly malicious, xenophobic, nor immoral in other ways. In this sense, they seemed to fit the existing image of a police force in a Scandinavian welfare state - police forces which in general are understood to be less corrupt and violent than those in other parts of the world. Although examples of problematic Danish and Scandinavian policing do exist (cf. Schclarek Mulinari 2017, Sollund 2007b, Kalkan 2018), these are minor and infrequent in comparison with, for instance, police in the US (Chaney and Robertson 2013, Ralph 2018), the UK (Keith 1993, Delsol and Shiner 2006, Loftus 2009, Holdaway and O'Neill 2006), France (Fassin 2013a), The Netherlands (Mutsaers 2019), India (Jauregui 2016), South Africa (Hornberger 2011, Steinberg 
2011, Diphoorn 2015) or Australia (Weber 2013), to mention a few other countries (see also Sluka 2010, Comaroff and Comaroff 2004, Garriott 2013, Weber and Bowling 2013, Fassin 2017, Karpiak and Garriott 2018). Nevertheless, in the above example, as well as in other examples that this article touches upon, the Danish detectives seemingly crossed moral lines in blunt and abysmal ways - in ways that were so obvious that they made it hard for me, the ethnographer, and for anyone else in the room, not to take notice.

This article asks the simple yet important question: how should we as police anthropologists-cum-ethnographers analyze such brutal police language? (see also Jauregui 2013). Initially, the article revisits conventional ways of analyzing police officers' backstage expressions of derogatory viewpoints or extreme violence - analytical ways that tend to see such expressions as either exemplary of an immoral and transgressive police force (but also of police officers who may feel that their immoral and transgressive means are justified by moral ends) (cf. Fassin 2013) or as a warped yet meaningful form of narratological venting, which, amongst other things, helps police officers make sense of a sometimes senseless and desensitizing job (cf. Waddington 1999). While I find such analysis sound and of significance in relation to my study of the Danish Police, this analytical framing tends to rule out, or overlook, a third option. The third option, elaborated in this article, is that some brutish police language - serious and extreme as it may appear - is largely ordinary and inconsequential. Using American philosopher Harry Frankurt's provocative yet pertinent theoretical treatise On Bullshit (2009), I argue that a lot of what the Danish detectives said was simply "bullshit" - a linguistic genre which surely is offensive but without any substantial meaning or purpose to it. This point relates to, and is substantiated by, the findings of other researchers of similar "masculine subcultures," such as the police (cf. Newburn and Stanko 1994, Gutmann 1997, Williams 2011). What these studies have shown is that various forms of mean yet meaningless talk are a recurrent part of these subcultures' everyday interactions. To be sure, an ethnographer of such social settings should not unassumingly bracket vicious wordings as inconsequential and analytically irrelevant. The transgressive things that, for example, police officers say need to be critically discerned. This article argues that we should not unconsciously and thus automatically let ourselves be drawn in by the extreme things the police say. If a connection between brutal language and everyday practices and perceptions can be established, this should unquestionably be pursued. Yet, in cases where a connection does not materialize, in the moment or later, we should also be able to take brutal talk less seriously - or, to stay with the loutish patois, "call bullshit."

\section{Culture or Sense-making: Two Prevalent Analytical Approaches Immoral Culture}

Scholars of policing have in general approached transgressive police language in two distinct yet overlapping ways: The first has to do with what in the literature is spoken of as "police culture," including the values, norms, and practices it furthers 
(cf. Cockcroft 2020). Loftus, in a fairly recent ethnography on the matter, has summarized the core tenets of police culture, namely that police officers are inherently conservative, often suspicious and skeptical toward outsiders, action-oriented, and having stereotypical masculine ideals (Loftus 2009). Translated into a specific moral code, police officers worldwide have become notorious for an (im)morality which seems old-fashioned, self-protective, aggressive, antagonistic, often xenophobic, and in general out of tune with a surrounding society that is becoming increasing globalized, multicultural and progressive in terms of gender equality and sexuality (cf. Loader and Mulcahy 2003, Fassin 2017). Bearing this in mind, offensive displays, like the one I witnessed when a group of Danish detectives were celebrating the death of certain foreign nationals, are frequently seen as a confirmation of how police forces and/or police officers still have a backward and callous cultural outlook. Their brutal outbursts are seen as Freudian slips where the ethnographer gets a rare glimpse into the actual reality of police perception - a reality otherwise hidden from outsiders (Van Maanen 1978). Similar points have been made in relation to analyses of the police's frequent use of jokes and bantering - self-proclaimed innocuous "fun and games" nevertheless seen as representing and fortifying racial or gendered hierarchies (Holdaway 1988, Westmarland 2001, Sollund 2007a, Granèr 2014, Lander 2016).

Furthermore, where some analyses are satisfied by their demonstration of what police culture consists of - as well as explaining how such a wicked culture can still exist as police cadets become socialized through the academy and by older colleagues into thinking in this way (Van Maanen 1973) - other analyses go a step further. Exemplary of this is Fassin's work on the Parisian police (Fassin 2013). Toeing the line of his proposed "anthropology of morality" (Fassin 2012) (see also Zigon 2007, Mattingly 2012), Fassin's analytical aim is not only to come up with an insular explanation of his police interlocutors' (im)morality. While he, in his ethnographic study, unearthed many of the same norms, values, and practices normally designated as "police culture," Fassin remained unsatisfied with merely concluding that this specific Parisian police unit was unnecessarily action-craving, aggressive, and discriminatory. He did witness actual instances of wrongdoing as well as an abundance of backstage displays of ostensibly brutal viewpoints, yet instead of bracketing these as simply immoral, he sought to demonstrate how his police interlocutors actually found their immoralities morally right. Put differently, Parisian officers were in fact well-aware that their doings and sayings can from the outside be seen as wicked and wrong. Nonetheless, spurred on by their own experience and a general discourse in France where certain migrant and minority groups have increasingly been portrayed as societal threats and criminogenic, the Parisian police officers found their discriminatory and brutal ways defensible and even honorable. They were, they themselves believed, just delivering the appropriate punishment to people who would otherwise slip through the cracks of an ineffective French legal system (see also Sykes 1986, Fassin 2018).

In this way, the Parisian police officers saw their immorality as a necessary evil mobilized to, in the end, make sure that justice was served (Fassin 2013). This re- 
lates directly to the policing scholar and criminologist Klockar's famous discussion of "the Dirty Harry problem" (Klockar 1980). Published in an anthology on Moral Issues in Police Work, Klockar uses Clint Eastwood's familiar portrayal of an American policeman, who in a wild quest to secure the conviction of a suspect - where little evidence is available but whose guilt he is certain of - uses a range of extralegal or "dirty" methods. Herein lies the "Dirty Harry problem" of much policing, namely that police officers often feel compelled to overstep moral and even legal boundaries to secure what they believe to be a moral and legal end. Be it in terms of falsifying probable cause or the application of excessive force, police officers in Denmark and around the world frequently step on or across the line of the law in their search for justice, thus paradoxically dirtying themselves for purist reasons (Holmberg 2003, Rowe and Søgaard 2019).

\section{Immoral Sense-making}

The previous section outlined an analytical framework in which brutal police language is seen as indexing bad police culture and, ultimately, practice, while attempting to humanize seemingly bad cops by explaining how their immoralities serve what they see as a moral end. To the police, what to outsiders appears to be a clear-cut display of moral corruption may entail a crude yet careful attempt to make sense of and enforce a wished-for social order.

In the second often-used analytical approach to the police's vicious ways of talking, sense-making is similarly in focus. This analytical approach springs out of studies of police storytelling and other forms of narrative performance (Shearing and Ericson 1991, Fielding 1994, Waddington 1999, Sollund 2007a, van Hulst 2013). As many researchers have noted, the police spend much of their downtime - of which there is a lot in both patrol and detective work - telling each other stories. Often, and on a par with the introductory example, such performances include issues of violence, xenophobia, misogyny, alongside other forms of brutishness, chauvinism and vulgarity. Such ruthless "canteen-talk" was the focus of Waddington's celebrated article on "Police (canteen) sub-culture" (1999). Waddington points to the way that many analyses of police (sub)culture tend to equate talk with action and presume that what the police say in the confines of the canteen is at least somewhat exemplary of their personal and professional attitudes and thus constitutes a potentially problematic influence on their practices (cf. Fassin 2013). Yet, Waddington maintains that there is little evidence substantiating a causative relationship between police utterances and their actions. Therefore, he argues, the police's canteen-talk, even its grimmer forms, should be seen less as evidencing police immorality and rather be appreciated as "expressive talk designed to give purpose and meaning to inherently problematic occupational experience" (1999:287).

This point ties directly to Hughes' celebrated writings on "dirty work" (1962) (see also Dick 2005) and, in the Scandinavian context, to Björk's (2008) examination of how Swedish police "fight cynicism". As Björk argues, brutal police language consists often performative and sense-making expressions aimed at peers rather than 
at the public - expressions that do not intend to inflict harm but to function as brutal yet helpful psychosocial linguistics by which the officers may talk about and deal with the strains of their "dirty/dirtying" profession. Van Hulst has more recently reiterated this point in his "Storytelling at the Police Station: The Canteen Culture Revisited" (2013) where he argues that "police storytelling is an understudied aspect of police culture(s)" (ibid: 624). It is understudied because backstage stories are a central way, Van Hulst maintains, for police to "make sense of things that are going on in their district [and a] narrative practice [by which] police officers shape their identity, and give meaning to their experiences, work and environment" (ibid: 638).

Focus on the meaning-making functions of storytelling has also long been a central tenet in the anthropology of violence and conflict (Feldman 1991, Jensen 1999, Scheper-Hughes and Bourgois 2004, Jackson 2002, Vigh 2006). Anthropologists studying social groups that lead violent lives have in a similar vein suggested that these individuals' many horrifying yet also glorifying stories about aggression and transgression should not unassumingly be explained away as nonsensical and boorish. Rather, crude forms of storytelling should also be appreciated as a means for violent and violated people to make sense of their harsh reality and, thereby, cast themselves and their doings as more than those of mere offenders vis-à-vis victims (see also Jauregui 2013). This is, for example, mirrored in Groes-Green's (2010) explanation of young Mozambiquien men's sexualizing, violent and even self-annihilating articulations. Groes-Green argues that such articulations are not just expressions of ire or ignorance but a form of expressive aesthetics where extreme transgressions become meaningful and even attractive in a deeply dysfunctional society. Other studies of vulgar banter and joking also suggest that these may be understood as a mad yet effective way for the joke-tellers to signal how they live in absurd and anxious circumstances - and thus, again, as a way to deal with this (Seizer 1997).

\section{Multifunctional Brutishness}

In the Scandinavian context, Granér has in his review of police (dark) humor and its relation to police practice argued that police humor, even in its darkest form, serves several functions beyond making sense of troublesome work or being an indicator-cum-generator of police practice (Granér 2014). Cruel mockeries, for example, function both as a way to reinforce the insider/outsider division between the police and the public and as a way to create internal hierarchies between officers of different sorts and ranks. Following this line of thought, it is thus important to acknowledge that the crude things police say to one another should not merely be understood as a matter of police culture or police sense-making. The things police officers talk about with one another are surely multifaceted "figurative actions" in the sense famously explored by Shearing and Ericson (1991), having a wide-ranging impact on police officers' practices, perceptions and their organization. What they say may appear strangely mythical and without much apparent consequence, yet nevertheless seeping into and shaping police habitus in a Bourdieusian sense (Chan 2004). This very much relates to Sandberg and Ugelvik's ar- 
gument (alongside those of other narrative criminologists) that even though selfrepresentations may not be directly factual, and sometimes are indeed wild fabrications, they are nonetheless consequential, albeit in less straightforward ways (Sandberg and Ugelvik 2016). In this way, there are nuances and additions to be made in relation to the analytical twofold presented in this article: i.e. that brutal police language is most-often analyzed either as indicative of a transgressive cultural outlook or as a mad yet meaningful form of sense-making. Yet, while bearing this in mind, in terms of quantity and impact, it would still be fair to say that the twofold is by and large emblematic of much of the existing work done on the matter (for a similar assertion, see Waddington 1999, Sollund 2007a).

\section{Cruel Wishes}

Having summarized the prevailing ways of interpreting transgressive police language, we may now take a look at some of the other brutal police expressions I encountered during my fieldwork. Below, I offer three short ethnographic examples of Danish detectives rather forcefully conveying what indeed seems to be very cruel wishes and viewpoints:

\section{Desecration!}

I have spent most of the day together with Detective Mikkelsen and Detective Olsen, staking out one of Copenhagen's most famous street festivals, Distortion. Looking for pickpockets and muggers, whilst zigzagging through the dense and drunken crowd of young urbanites, the detectives have eventually decided to call it a day. Unfortunately, seen from a police perspective, they did not make any arrests today, although the detectives did stop and question a couple of Polish men who they, ultimately, decided to let go. "I hate it when they present themselves as angels and start complaining. It's a sham, for sure. I'll bet you that this is not the last we see of them," Detective Mikkelsen says with reference to the two Polish men, as we slowly leave the festival behind. We get into the detectives' car. Detective Olsen turns the key, turns on the radio, and we set off towards the police station. "Boring day today, eh?" Detective Mikkelsen concludes. "Yup," his partner answers as the radio starts crackling. Now, listening to the radio, the detectives get a report about a cemetery having been massively desecrated. "Yeah!" Detective Olsen yells. "Smash it all!" "Haha," Detective Mikkelsen laughs in agreement. "Yup, I'm not going to be looking that hard for any suspects," he says, catching my eye and smiling at me in the rearview mirror. I smile back, sort of, listening to the ill-mannered sound of the two detectives discussing in detail what they would do to the gravestones if they had the time and a sledgehammer - an absurd conversation which only becomes more and more elaborate and passionate until we park the car, enter the station, salute a couple of colleagues, grab three cups of coffee, and sit down to relax at the big communal table outside their office.

\section{Skull Crushing!}

As tourists have their eyes fixed on the - to many first beholders - underwhelming yet world-famous Copenhagen statue of the Little Mermaid, Detectives Clausen, 
Christensen, Mikkelsen, and Larsen scan the surrounding crowd of tourists, looking for potential thieves hiding in the throng. The detectives tell me that tourist sites and busy public places in general are the preferred hunting grounds for an array of international pickpockets including "credit card thieves" and "police imposters," the former stealing and using people's debit/credit cards, the latter posing as Danish police officers, especially with Asian tourists who rarely question authorities and, it is believed, cannot tell the difference between how Scandinavians and Eastern Europeans look. Approaching chosen tourists, the police imposters then demand that they identify themselves and, whilst flicking through their wallets, steal their cash, bank cards and other valuables.

Yesterday, the detectives caught a couple of police imposters, but today they have received reports that there are more imposters, or "fake cops" as they also call them, on the loose. The detectives are therefore on high alert. This has also something to do with how they see people posing as police officers as not only a severe crime but as making a mockery of the police profession. The severity and mockery of the crime is even inscribed into the criminals' own description of the crime - a crime they term "the Maradona" with reference to the brilliant yet scandalous Argentinian football magician. Standing on a small hill overlooking the Little Mermaid, a small harbor, and Copenhagen's old fortress, Detective Larsen starts to reminisce. Together with Detective Clausen, he tells me about how "last summer, we caught two Polish police imposters."

"This is where we spotted them as they were trying to trick an elderly Japanese couple," Detective Larsen says. "But, as we approached them, they unfortunately spotted us and made a run for it. I myself quickly caught one of them and cuffed him. The other, however, Detective Christensen had to chase on foot. He was a quick fucker and managed to escape, crossing the train tracks. Now, Detective Christensen was keeping us in the loop on the radio, so Detective Mikkelsen drove the car to the train station and ran onto the station platform. So, when the Polish dude climbed on to the platform, Detective Mikkelsen was already there and they started to tussle. Unfortunately, he couldn't handle him so easily, so they both fell down onto the tracks. That's super dangerous, you know, with trains coming and going. Fortunately, no trains came and Detective Mikkelsen managed to pacify the suspect with his pepper spray. He then dragged him up onto the platform where Detective Christensen was now waiting. Together they cuffed him and brought him back to the station. I mean," Detective Larsen says, thinking about it, "if I'd been there as well, I would have loved to give this imposter a serious beating. He put us in danger by fleeing onto the tracks and by resisting arrest. Guys like him need to taste the baton! Seriously, we should have beaten him so that he would remember not to act like a fool. I personally would have loved to smash him into a goddamn pulp! 100\% skull crushing! Seriously! It wouldn't be the correct thing to do, but it would be my kind of justice," Detective Larsen concludes smilingly, clinching and swinging his fist. 


\section{Filthy Animals!}

"Pass me the hand sanitizer! Hurry up!" Detective Andersen urges her colleague. "Patience! I need to use it as well. These people are so fucking filthy. Disgusting animals!" Detective Olesen replies energetically, as he squeezes what seems to be half a bottle of alcogel into the palm of his left hand. "There," he mutters in relief as he passes the bottle to his colleague and rubs his hands together. "Saved by the bell. Probably not going to get the plague this time either." "Haha. Fingers crossed!" Detective Andersen responds, as she also cleans her hands and wrists before we exit Vestre Penitentiary [Copenhagen's biggest jail] and head towards the next task of the day. En route, however, she suddenly remembers that I too, the ethnographer in the backseat, had been in danger. "So sorry, David! I totally forgot that you just also risked your life. Here you go," she says, throwing me the hand sanitizer.

Animated displays of revulsion about how filthy and nauseating they thought suspects were, was something I occasionally encountered doing the time I spent with the two detective units. Sometimes, the detectives would almost try to outdo one another in illustrating how ominous they thought many suspects were. This was however never something that came to the fore when the detectives were interacting with suspects. Here, for example, their alleged great fright of being infected did not surface, nor did their purported sadistic aspirations like those mentioned in the case of the cemetery and the police imposter. Nor were these brutal expressions something that on average seemed to shape their general perception of various suspects when they otherwise ran their cases or discussed them with each other - or with me, for that matter. Furthermore, and notably, after having said outrageous things like the above, the detectives often, to paraphrase Das (2016), descended directedly into the ordinary. They would rage on their about violent and vulgar fantasies, only, at almost the next second, to seem completely unaffected by them. For me, the ethnographer witnessing such worded brutishness, the paradoxical disconnect between the detectives' words and everyday reality left me perplexed. How was I to make sense of what appeared to be distressing examples of police cruelty and an everyday reality that, nonetheless, remained largely unaffected?

\section{Real Shit or Bullshit?}

So far, this article has produced some disturbing examples of vicious police language. And as the Danish detectives themselves openly admitted to me, "it definitely wouldn't look good if these things were to end up on the front page of the newspapers" - worries resonating with Reiner and Newburn's (2007) contention that the police not infrequently utter tabloid worthy language. Yet, even though the detectives knew very well that what they were saying was scandalous, they kept on airing, even with me around, what could easily be interpreted as evidence either of an immoral police culture or as examples of a, to outsiders, uncouth yet, to the police, formative form of storytelling. 
But was this the case? Certainly, I am not going to deny that the detectives' foul mouths were, in some sense at least, indicative of their norms and values, nor do I want to disregard the view that their brutal expressions may have served a perverted yet narratological purpose in relation to a profession that involves many instances of human corruption. However, I also believe that this analytical twofold has some potential shortcomings. More to the point, I believe that by continuously treating police backstage expressions as ultimately analytically indexing either police culture or sense-making - or for that matter as otherwise figuratively functional or narratologically consequential to the police - one runs the risk of taking police brutishness too seriously. Indeed, where Van Hulst may be right to point out that "police storytelling is an understudied aspect of police culture(s)" (Van Hulst 2013: 624) compared to other aspects of police work, the claim of this article is that police storytelling, and especially that of the more brutal sort, also tends to be overstudied. In police research, brutal and transgressive language is, as I argue, occasionally overestimated and overinterpreted as particularly meaningful though it often means very little. This may very well seem counterintuitive as it sounds extreme and thus evocative to the ethnographer. Nevertheless, it is, as one of the Danish detectives put it, "often more bullshit than real shit. You know, sometimes we just say stupid shit for the sake of it."

\section{On Bullshit}

Indeed, "saying stupid shit for the sake of it" does point to a specific jargon frequently found among police officers and other masculine subcultures. Acting stupid and brutal in front of your peers has its own weird form of interactional value. It displays indifference, roughness, as well as being indicative of an appreciated usagainst-the-world attitude (cf. Newburn and Stanko 1994, Waddington 1999, Granér 2014). Yet, it is also a linguistic genre in its own right known to all of us; a genre which the American Philosopher Harry Frankfurt simply yet fittingly termed and theorized as 'bullshit' (2009). As Frankfurt writes in the introduction to his book On Bullshit, "one of the most salient features of our culture is that there is so much bullshit. Everyone knows this. Each of us contributes his share" (Frankfurt 2009:1). Yet, even though we all know this, and take part in bullshitting, contrary to what we think, most of us have a hard time recognizing bullshit. To Frankfurt, this has to do with the fundamental laxity of bullshitting. Bullshit, for example, is not the same as telling a lie. Though the liar does not tell the truth, he actually cares deeply about the truth as his lie is exactly construed as a distortion of the truth/facts. Furthermore, the liar is very concerned with how his lie is received. There is a specific (mis)information which the liar wants to be conveyed and acted on. The bullshitter, on the other hand, is indifferent to what is right or wrong. Bullshit, Frankfurt argues, is like "hot air," i.e. "speech that has been emptied of all informative content" (Frankfurt 2009:13). In this way, it resembles LeviStrauss's famous musings on "floating signifiers"- a floating signifier being a signifier without any particular referent and thus both void yet indefinite in a semiotic sense (Levi-Strauss 1950). 
What bullshit essentially misrepresents is neither the state of affairs to which it refers nor the beliefs of the speaker concerning that state of affairs ... The bullshitter may not deceive us, or even intend to do so, either about the facts or about what he takes the facts to be. What he does necessarily attempt to deceive us about is his enterprise (Frankfurt 2009:4).

As the above shows, bullshit may be understood both as a prevalent societal phenomenon - something we all engage in - as well as a specific genre with no strict reference point in reality or informative aim. Instead, it involves the uttering of deliberately empty or ephemeral words with the intention of saying nothing as such about what one really thinks and wants. The bullshitter's aim is, most of all, to be evocative and disconcerting, illusive rather than informative.

\section{Danish detective bullshit}

Frankfurt - with a view to American politics and public life - looks at bullshitting as a largely negative enterprise. Yet, if we bracket such normativity and simply look at bullshit as a specific linguistic genre, Frankfurt's analysis of the essence of bullshit and how it works is theoretically informative, especially in relation to this article's attempt to understand the Danish detectives' brutish argot. Returning to the ethnographic examples, what unites them is exactly that, on the one hand, they are conspicuous, vile and vulgar, whilst, on the other hand, they by and large have little reference or relevance to the detectives' everyday practices and perceptions. Besides being obviously provocative, they do not seem to be informative of or to have any obvious purchase on the detectives' profession - something the many months I spent with the detectives confirmed. Being with the detectives, night and day, at work and off work, for many hundreds of hours never gave me any evidence of their expressed brutishness consistently finding its way into their workday - something which remains true today when I occasionally speak to them and observe their actions. While their transgressive language did on occasion have dire consequences, most of all, as the detectives also admitted, they spoke like this because they wanted "to stir things up." Yet, as my observations of with the detectives showed me, almost as soon as they had finished verbally "stirring things up," they quickly fell back into a more reasonable and much less brutal normality.

The simple, albeit controversial, claim put forward in this article is that one way to understand the police's despicable talk would be to see it - at least sometimes less as an example of police immorality or professional therapeutics and more as an example of bullshitting - a jargon that not only Danish detectives but police around the world happily engage in (cf. Loftus 2009, Fassin 2013, Cockcroft 2020). Following Frankfurt, the intention behind what is said is to make it appear like hot air - as remarkably fiery and scorching, as something for peers to notice and feel, but not to act on. The Danish detectives, I would argue, and they would confirm, were sometimes saying stupid things for the sake of saying stupid things bullshitting for the sake of bullshitting. And, importantly, all the detectives knew this. Just like all of us pretty much know when our friends, family or close col- 
leagues are serious or not, the Danish detectives were almost always able to detect when colleagues were bullshitting and when they were being real and earnest. Yet, as Frankfurt correctly maintains, to an outsider like me, and to many fellow police ethnographers (cf. Waddington 1999, Westmarland 2001), it is admittedly often hard to know whether to take police or other bullshitters seriously or not.

\section{Illegal fantasies}

I anticipate that my supplementary reading of brutal police patois as "just" bullshit may result in accusations that I have lost critical edge and even "gone native." Nevertheless, in my reasoning, I follow in the footsteps of other anthropologists and ethnographers who have studied similar social groups and masculine subcultures. Bullshitting - and other kinds of intentionally illusive talk - obviously extend beyond the world of police officers. Two telling examples come to mind, although there are surely many more. The first involves that of young men involved in criminal and gang-like activities, sometimes designated as "street corner societies" or "street cultures" (Anderson 1999, Bourgois 2003, Whyte 2012). Even in this masculine subculture insiders spend a lot of time telling wild stories about what they think about life and what they want from it. Ethnographic studies from Denmark and beyond have demonstrated that people in masculine subcultures frequently talk about how they want to get fantastically wealthy, have sex with a lot of girls, drive extravagant cars, wear expensive clothes, have all the accessories, own a palace-like home, and, to achieve this, beat up or kill anyone who disrespects them and stands in their way (Sandberg and Pedersen 2011, Sandberg and Fleetwood 2017, Kalkan 2018). Tellingly, as Kalkan has shown through his year-on-year ethnographic study of a group of young ethnic minority men in Nørrebro, Copenhagen, two of their greatest "role models" or "idols" are, respectively, Tony Montana and Tupac Shakur - a fictional murderous mobster and a murdered gangsta rapper (Kalkan 2018).

When conducting ethnography on street corners, the ethnographer will ultimately have to decide how to analyze such apparently illegal and immoral fantasies. But it would amount to a very simplistic and problematic analysis if one decided to take the young men's stories and statements at face value - as if they all truly aspire to be wealthy yet vicious human beings. Numerous studies have shown how their debauched aspirations are in fact more fictional fantasies than factual imaginaries (cf. Bourgois 2003, Ralph 2014). Although they often speak of becoming Tony Montana, or a similar criminal persona, they(mostly) do not really think that they will become him, nor, importantly, do they really want to. What most of them genuinely want is of a much more modest and traditional sort. They want a job, a roof over their heads, friends, a family and to be respected by their peers and by the society around them. Their illegal fantasies are thus more of a conspicuous yet largely purposeless pose or pastime rather than a figurative and functional speechact representing or in other words relating to their norms and values and future practice - bullshit more than realism. 
Another telling example from anthropological literature is that of young impoverished men from the global south who wish to migrate to the better-off parts of the world. As documented by many anthropologists, these young males also engage in a lot of spirited exchanges about how they picture their future lives in, for example, Europe or the US. Exemplary of this is Vigh's extensive work on young Guinea Bissauan men migrating to Europe, often by means of becoming cocaine traffickers (Vigh 2015, 2017). In speaking to the men about what they believe their lives in Europe will be like, they talk about how they will use their cocaine trafficking as a "trampoline of life" (Vigh 2016). Initially they maintain that it will make them rich, get them fast cars, many women, and that they will probably also become famous footballers, whilst being able to support their families back in Bissau. However, as Vigh underlines, these tales are mere tales, illusory and even self-admitted absurd fantasies and, hence, not what the men actually imagine will happen. The young men know very well that they will not become flush cocaine kingpins and kings of the world. Quite to the contrary. They do not wish to live a life of violence. They would prefer not to be criminals. And they are certainly well aware that they are at the bottom of society in Bissau and will, sadly, remain at the bottom of society when they get to Europe (Vigh 2019). To use Frankfurt's idiom, their fantasies are but bullshit. Something they are painfully aware of themselves, but which they allow each other to air without feeling it necessary for anyone to openly puncture the fantasy.

\section{Conclusion}

On occasion, as I have argued, we need to take brutal police language less seriously. This does not mean that the offensive things police say when they are amongst themselves should always be disregarded as analytically insignificant. There is indeed a recurring connection between crude police argot and violent practices across the globe. Such connections need to be without doubt discussed. That being said, there is also a clear divide between the things police officers say in their offices, cars and canteens and their actual practice. In these cases, one should be hesitant about taking these wild backstage articulations as if they are necessarily indicative of police immorality and misconduct. Moreover, some hesitance is also required in interpreting their stories in terms of sense-making socio-linguistics. Certainly, it is sometimes correct to point out that police tell stories - and outrageous ones - in order to reflect on and possibly come to terms with a demanding and sometimes ruthless working reality. Nonetheless, some of the brutal things police say to each other are just "bullshit" - immoral in form but substantively inconsequential. Put in Frankfurt's terminology, the police's foulmouthed ways are clearly offensive yet not inevitably representing "the state of affairs to which it refers nor the beliefs of the speaker concerning that state of affairs" (Frankfurt 2009:13). The Danish detectives' abhorrent articulations were often just hot air rather than an honest airing of opinion. They were in many cases not trying to communicate or reflect on something specific when uttering their violent and vicious fantasies. They were not trying to display or sway opinion. Mostly, they were simply trying to be brutal for the sake of being brutal - bullshitting for the sake of bullshitting. 
This surely says something about the peculiar way police officers like to engage with each other. However, it does not - as much literature written on the matter tends to suggest - necessarily say anything substantial about their perceptions or practices. As a detective himself admitted, "We are obviously being obscene when saying stuff like that. And, yes, we know it's tasteless, but that's the point really. Besides that, there's often no real point to it." Again, as an ethnographer, one should not too easily buy into police officers' playing down of the offensive things they say. It might be a conscious or unconscious way of camouflaging their vices. In those cases where nothing substantial seems to spring from their seemingly iniquitous talk, one should however also be prepared to say that there is not much to it. This is important. It is methodologically and analytically important because if we take brutal backstage talk too seriously, we run the risk of misrepresenting the world we study. Yet, it is also important in terms of research ethics. If we excessively focus on and thus overinterpret the absurd things police officers - or other people for that matter - say, we risk not only misrepresenting our interlocutors but portraying them as malicious, antagonistic fools. Contrary to the humanizing endeavor, which Karpiak and Garriott (2018) have wisely made central to their anthropology of policing, by overinterpreting police bullshit we risk dehumanizing police officers, portraying them not only as evil-minded but also as simple-minded.

This article can therefore be said to initially agree with Fassin's apt contention that "not enough [anthropological] attention has been provided to ambiguous moral forms and ethical positions" (Fassin 2013b, 249). Too often, emotional outbursts, such as intense displays of resentment or ire, are dealt with in representational or reductive ways - as indexing views on, or ways of, life (Fassin 2013b). One reason for this may be that such outbursts are often both very conspicuous yet also inapprehensible to the beholder. This may be true to many academics whose moral compass is habitually shaped by an unhazardous, intellectual, and, understandably, politically correct raison d'être. As academics, even as anthropologists-cumethnographers, we live lives largely removed from everyday instances of violence, vice, and hostility. Yet, to many other people, the police included, such animosity is habitual. This inevitably shapes their language - and not necessarily just in antagonistic ways or for curative reasons, but simply because it becomes a normal way of interacting. They may say brutal things but the things they say may not always mean much. Herein lies a banal yet additional approach to Fassin's assertion that anthropologists should become better at studying otherwise difficult-to-understand moral forms. We should sometimes pay not more but less attention to some forms of expressed (im)morality and heinousness. Sometimes police and others just bullshit. In fact, as Frankfurt has reminded us, so do we all. This is indeed an aggravating aspect of human interaction but nevertheless something where we, especially as researchers, need to be able to call bullshit rather than being bullshitted.

\section{Author Bio}

David Sausdal is a Postdoc and ethnographer at the Centre for Global Criminology, Department of Anthropology, University of Copenhagen. His current research 
focuses on issues of transnational crime and policing - issues which he has published on in journals such as Theoretical Criminology, European Fournal of Criminology, Policing and Society and Focaal: Fournal of Global and Historical Anthropology.

\section{Funding}

Research for this article is supported by funding from the European Research Council (ERG) under the European Union's Horizon 2020 research and innovation programme (grant agreement CRIMTANG - \#725194).

\section{References}

Anderson, Elijah. 1999. Code of the Street: New York: Norton.

Björk, Micael. 2008. "Fighting cynicism: some reflections on self-motivation in police work." Police quarterly 11 (1):88-101. https://doi.org/10.1177/1098611107309010

Bourgois, Philippe. 2003. In search of respect: Selling crack in El Barrio. Cambridge: Cambridge University Press. https://doi.org/10.1017/CBO9780511808562

Chan, Janet. 2004. "Using Pierre Bourdieu's framework for understanding police culture." Droit et société (1):327-346.

https://doi.org/10.3917/drs.056.0327

Chaney, Cassandra, and Ray Robertson. 2013. "Racism and police brutality in America." Journal of African American Studies 17 (4):480-505. https://doi.org/10.1007/s12111-013-9246-5

Cockcroft, Tom. 2020. Police Culture: Research and Practice. Bristol: Policy Press.

Comaroff, John, and Jean Comaroff. 2004. "Policing culture, cultural policing: law and social order in postcolonial South Africa." Social Inquiry 29

(3):513-545.

https://doi.org/10.1111/j.1747-4469.2004.tb00999.x

Das, Veena. 2016. "Lecture 2: What does ordinary ethics look like?" In Four lectures on ethics, edited by Michael Lambek, Veena Das, Didier Fassin and Webb Keane. London: Hau books.

Delsol, Rebekah, and Michael Shiner. 2006. "Regulating stop and search: a challenge for police and community relations in England and Wales." Critical criminology 14 (3):241-263. https://doi.org/10.1007/s10612-006-9013-1 
Dick, Penny. 2005. "Dirty work designations: How police officers account for their use of coercive force." Human relations 58 (11):1363-1390. https://doi.org/10.1177/0018726705060242

Diphoorn, Tessa G. 2015. Twilight policing: Private security and violence in urban South Africa. Berkeley, CA: University of California Press. https://doi.org/10.1093/bjc/azv057

Fassin, Didier. 2012. A companion to moral anthropology. Chichester: John Wiley \& Sons. https://doi.org/10.1002/9781118290620

Fassin, Didier. 2013a. Enforcing order: an ethnography of urban policing. Cambridge, UK: Polity Press.

Fassin, Didier. 2013b. "On resentment and ressentiment: the politics and ethics of moral emotions." Current anthropology 54 (3). https://doi.org/10.1086/670390

Fassin, Didier. 2017. Writing the World of Policing: The Difference Ethnography Makes. Chicago, IL: University of Chicago Press. https://doi.org/10.7208/chicago/9780226497785.001.0001

Fassin, Didier. 2018. The Will to Punish. Oxford: Oxford University Press. https://doi.org/10.1093/oso/9780190888589.001.0001

Feldman, Allen. 1991. Formations of violence: The narrative of the body and political terror in Northern Ireland. Chicago: University of Chicago Press. https://doi.org/10.7208/chicago/9780226240800.001.0001

Fielding, Nigel. 1994. "Cop canteen culture." In Just boys doing business, edited by T Newburn and EA Stanko, 46-63. London: Routledge.

Frankfurt, Harry G. 2009. On bullshit. Princeton, NJ: Princeton University Press.

Garriott, William. 2013. Policing and contemporary governance: The anthropology of police in practice. New York,NY: Palgrave. https://doi.org/10.1057/9781137309679

Goffman, Erving. 1978. The presentation of self in everyday life. Harmondsworth: Penguin.

Granèr, Rolf. 2014. "Humorns funktion i polisarbetet." Nordisk politiforskning 1 (01):9-23. 
Groes-Green, Christian. 2010. "Orgies of the moment: Bataille's anthropology of transgression and the defiance of danger in post-socialist Mozambique." Anthropological Theory 10 (4):385-407. https://doi.org/10.1177/1463499610386662

Gutmann, Matthew. 1997. "Trafficking in men: The anthropology of masculinity." Annual review of Anthropology 26 (1):385-409. https://doi.org/10.1146/annurev.anthro.26.1.385

Holdaway, Simon. 1988. "Blue jokes: Humour in police work." In Humour in Society, 106-122. New York, NY: Springer. https://doi.org/10.1007/978-1-349-19193-2_6

Holdaway, Simon, and Megan O'Neill. 2006. "Institutional racism after Macpherson: an analysis of police views." Policing and Society 16 (4):349-369. https://doi.org/10.1080/10439460600967885

Holmberg, Lars. 2003. Policing stereotypes: a qualitative study of police work in Denmark. Glienicke, Brandenburg: Galda \& Wilch.

Hornberger, Julia. 2011. Policing and Human Rights: the meaning of violence and justice in the everyday policing of Johannesburg. Abingdon, Oxon: Routledge. https://doi.org/10.4324/9780203819975

Hughes, Everett C. 1962. "Good people and dirty work." Social problems 10 (1):311. https://doi.org/10.2307/799402

Jackson, Michael. 2002. The politics of storytelling: Violence, transgression, and intersubjectivity. Vol. 3. Copenhagen: Museum Tusculanum Press

Jauregui, Beatrice. 2013. "Dirty anthropology: Epistemologies of violence and ethical entanglements in police ethnography." In Policing and Contemporary Governance, edited by William Garriott, 125-153. New York, NY:

Springer. https://doi.org/10.1057/9781137309679 6

Jauregui, Beatrice. 2016. Provisional authority: police, order, and security in India. Chicago, IL: University of Chicago Press. https://doi.org/10.7208/chicago/9780226403847.001.0001

Jensen, Steffen. 1999. "Discourses of violence: coping with violence on the Cape Flats." Social Dynamics 25 (2):75-97. https://doi.org/10.1080/02533959908458676 
Kalkan, Hakan. 2018. Shababs: Gadekultur, gadens økonomi og respekt-på Nørrebro. Copenhagen: University of Copenhagen. Doctoral thesis.

Karpiak, Kevin G, and William Garriott. 2018. The anthropology of police. New York: Routledge. https://doi.org/10.4324/9781315687759

Keith, Michael. 1993. Race, riots and policing: lore and disorder in a multi-racist society. London: Ucl Press.

Klockars, Carl B. 1980. "The dirty Harry problem." The Annals of the American Academy of Political and Social Science 452 (1):33-47. https://doi.org/10.1177/000271628045200104

Lander, Ingrid. 2016. "Doing the Right Masculinities Right: The Police Force as Gendered Practices 1." In Masculinities in the Criminological Field: Control, Vulnerability and Risk-Taking, edited by Ingrid Lander, Signe Ravn and Nina Jon, 71. Milton Park: Taylor \& Francis. https://doi.org/10.4324/9781315594132-5

Lévi-Strauss, Claude. 1950. "Marcel Mauss." Cahiers internationaux de sociologie 8:72-112.

Loader, Ian, and Aogan Mulcahy. 2003. Policing and the condition of England: memory, politics and culture. Oxford: Oxford University Press. https://doi.org/10.1093/acprof:oso/9780198299066.001.0001

Loftus, Bethan. 2009. Police culture in a changing world. Oxford: Oxford University Press.

https://doi.org/10.1093/acprof:oso/9780199560905.001.0001

Mattingly, Cheryl. 2012. "Two virtue ethics and the anthropology of morality." Anthropological Theory 12 (2):161-184. https://doi.org/10.1177/1463499612455284

Mutsaers, Paul. 2019. Police Unlimited: Policing, Migrants, and the Values of Bureaucracy. Oxford: Oxford University Press. https://doi.org/10.1093/oso/9780198788508.001.0001

Newburn, Tim, and Elizabeth A Stanko. 1994. Just boys doing business? London: Routledge.

Ralph, Laurence. 2014. Renegade dreams: Living through injury in gangland Chicago. Chicago: University of Chicago Press. https://doi.org/10.7208/chicago/9780226032856.001.0001 
Ralph, Laurence. 2018. "The Black Box of police torture." In The Anthropology of Police, edited by Kevin Karpiak and William Garriott, 188-208. New York: Routledge. https://doi.org/10.4324/9781315687759-12

Reiner, R, and R Newburn. 2007. Police research. I: R. King \& E. Wincup (red.) Doing Research on Crime and Justice. Oxford: Oxford University Press.

Rowe, Mike, and Thomas Friis Søgaard. 2019. "'Playing the man, not the ball': targeting organised criminals, intelligence and the problems with pulling levers." Policing and Society:1-16. https://doi.org/10.1080/10439463.2019.1603226

Sandberg, Sveinung, and Jennifer Fleetwood. 2017. "Street talk and Bourdieusian criminology: Bringing narrative to field theory." Criminology and Criminal Justice 17 (4):365-381.

https://doi.org/10.1177/1748895816672909

Sandberg, Sveinung, and Willy Pedersen. 2011. Street capital: Black cannabis dealers in a white welfare state. Bristol: Policy Press. https://doi.org/10.1332/policypress/9781847421203.001.0001

Sandberg, Sveinung, and Thomas Ugelvik. 2016. The past, present, and future of narrative criminology: A review and an invitation. London: SAGE. https://doi.org/10.1177/1741659016663558

Sausdal, David. 2018a. "Everyday deficiencies of police surveillance: a quotidian approach to surveillance studies." Policing and Society. doi: 10.1080/10439463.2018.1557659. https://doi.org/10.1080/10439463.2018.1557659

Sausdal, David. 2018b. "Pleasures of policing: An additional analysis of xenophobia." Theoretical Criminology 22 (2):226-242. doi: $10.1177 / 1362480617707947$. https://doi.org/10.1177/1362480617707947

Sausdal, David. 2019a. "Policing at a distance and that human thing: An appreciative critique of police surveillance." Focaal 2019 (85):51-64. https://doi.org/10.3167/fcl.2019.850105

Sausdal, David. 2019b. "Terrorizing police: Revisiting 'the policing of terrorism'from the perspective of Danish police detectives." European Journal of Criminology. doi: 1477370819874449. https://doi.org/10.1177/1477370819874449 
Schclarek Mulinari, Leandro. 2017. Slumpvis utvald. Solna: Civil Rights Defenders and Stockholm University.

Scheper-Hughes, Nancy, and Philippe Bourgois. 2004. Violence in War and Peace: an anthology. Malden, MA: Blackwell.

Seizer, Susan. 1997. "Jokes, gender, and discursive distance on the Tamil popular stage." American Ethnologist 24 (1):62-90.

https://doi.org/10.1525/ae.1997.24.1.62

Shearing, Clifford D, and Richard V Ericson. 1991. "Culture as figurative action." British Journal of Sociology:481-506. https://doi.org/10.2307/591444

Sluka, Jeffrey A. 2010. Death squad: The anthropology of state terror. Philadelphia University of Pennsylvania Press.

Sollund, Ragnhild. 2007a. "Canteen Banter or Racism: is there a Relationship between Oslo Police's Use of Derogatory Terms and their Attitudes and Conduct towards Ethnic Minorities?" Journal of Scandinavian studies in criminology and crime prevention 8 (1):77-96.

https://doi.org/10.1080/14043850601030057

Sollund, Ragnhild. 2007b. Tatt for en annen: en feltstudie av relasjonen mellom etniske minoriteter og politiet. Oslo: Gyldendal akademisk.

Steinberg, Jonny. 2011. "Security and disappointment: policing, freedom and xenophobia in South Africa." The British Journal of Criminology 52 (2):345-360.

https://doi.org/10.1093/bjc/azr069

Sykes, Gary. 1986. "Street justice: A moral defense of order maintenance policing." Justice Quarterly 3 (4):497-512. https://doi.org/10.1080/07418828600089081

van Hulst, Merlijn. 2013. "Storytelling At The Police Station The Canteen Culture Revisited." British journal of criminology 53 (4):624-642. https://doi.org/10.1093/bjc/azt014

Van Maanen, John. 1973. "Observations on the making of policemen." Human organization $32(4): 407-418$. https://doi.org/10.17730/humo.32.4.13h7x81187mh8km8

Van Maanen, John. 1978. "The asshole." In Policing: A view from the street, edited by Peter K Manning and John Van Maanen, 221-238. Chicago, IL: Goodyear Publishing. 
Vigh, Henrik. 2015. "Mobile misfortune." Culture Unbound: Journal of Current Cultural Research 7 (2):233-253. https://doi.org/10.3384/cu.2000.1525.1572233

Vigh, Henrik. 2016. "Life's trampoline: on nullification and cocaine migration in Bissau." In Affective Circuits: African Migrations to Europe and the Pursuit of Social Regeneration, edited by Jennifer Cole and Christian Groes, 223. Chicago: University of Chicago Press. https://doi.org/10.7208/chicago/9780226405292.003.0010

Vigh, Henrik. 2017. "Caring through crime: ethical ambivalence and the cocaine trade in Bissau." Africa 87 (3):479-495. https://doi.org/10.1017/S0001972017000079

Vigh, Henrik. 2019. "Life in the ant trails: Cocaine and caustic circuits in Bissau." Focaal 2019 (85):15-25. https://doi.org/10.3167/fcl.2019.850102

Vigh, Henrik E. 2006. Navigating terrains of war: Youth and soldiering in Guinea-Bissau. Vol. 13. Oxford: Berghahn Books. https://doi.org/10.1111/j.1467-9655.2007.00455_16.x

Waddington, Peter AJ. 1999. "Police (canteen) sub-culture. An appreciation." British journal of criminology 39 (2):287-309. https://doi.org/10.1093/bjc/39.2.287

Weber, Leanne. 2013. Policing non-citizens. Abingdon, Oxon: Routledge. https://doi.org/10.4324/9780203070505

Weber, Leanne, and Ben Bowling. 2013. Stop and search: Police power in global context. Abingdon, Oxon: Routledge. https://doi.org/10.4324/9781315873237

Westmarland, Louise. 2001. "Blowing the whistle on police violence. Gender, ethnography and ethics." British Journal of Criminology 41 (3):523-535. https://doi.org/10.1093/bjc/41.3.523

Whyte, William Foote. 2012. Street corner society: The social structure of an Italian slum. Chicago: University of Chicago Press.

Williams, J Patrick. 2011. Subcultural theory: Traditions and concepts. Cambridge: Polity.

Zigon, Jarrett. 2007. "Moral breakdown and the ethical demand a theoretical framework for an anthropology of moralities." Anthropological Theory 7 
David Sausdal - Police Bullshit

(2):131-150.

https://doi.org/10.1177/1463499607077295 